\title{
Circulation of Leachate Organic Solid Waste in Fixed Bed Reactor with Pressure Swing Absorption Technology
}

\author{
Etih Hartati $^{*}$, Ikrima Nurul Amaliyah, and Salafudin \\ Department of Environmental Engineering, Institut Teknologi Nasional (Itenas) Bandung - Indonesia
}

\begin{abstract}
Treatment of solid waste that can be applied to reduce solid waste into the landfill is the treatment of organic solid waste into a biogas. The largest component of biogas is $\mathrm{CH}_{4}$ and $\mathrm{CO}_{2}$ Alternative organic solid waste treatment is anaerobic digestion, besides reducing waste, this process can also produce renewable fuels. This research processed the leachate organic solid waste from Itenas cafetaria using fixed bed reactor. Volume reactor 180 liters with sponge filter media. An increase the concentration gas $\mathrm{CH}_{4}$ conducted using pressure swing absorption technology with pressure 1 bar on the reactor metanogen and $-0,01$ bar on stripper. Variation circulation a substrate for $0,30,0,32$, and 0,33 circulation per hour. Parameter measured are COD, TVA, $\mathrm{pH}$, temperature, alkalinitas, and $\mathrm{CO}_{2}, \mathrm{CH} 4$. The result of this research obtained gas $\mathrm{CH}_{4}$ highest concentration of $90 \%$ in a gas holder metanogen, and the highest $\mathrm{CO}_{2} 24,36 \%$ in a gas holder stripper on volumetric 0,33 circulation/hours.
\end{abstract}

Keyword; Methane; pressure swing absorption; leachate

\section{Introduction}

Organic waste can be utilized as a source of renewable energy such as biogas, biogas is now widely adopted as a substitute for fossil energy began to experience a crisis. The content of the biogas is composed of a mixture of gases, the most dominant gas is $\mathrm{CH} 4(50-70 \%)$ and $\mathrm{CO} 2$ (25-45\%) and other gases with small concentrations [1].

Biogas has a high calor value, which is in the range of 4800-6700 kcal / m3, for pure methane gas (100\%) has a calor value of $8900 \mathrm{kcal} / \mathrm{m}^{3}$ [2]. Biogas began to be developed in Indonesia around 1970. However, the high use of kerosene fuels and the availability of fuel wood caused the use of biogas to become less developed. Biogas technology began to develop again since 2006 when the scarcity of energy became the main topic in Indonesia [3].

In general, the anaerobic process is divided into three stages, namely the hydrolysis stage, the acidogenesis stage, and finally the methanogenesis stage. Anaerobic degester commonly used is one stage digester and two stage digester, one stage digester design is easier, simpler, and low in investment costs [4]. Two stage digesters have a configuration process that separates the asogenogenesis and methanogenesis reactors that are connected in series, enabling the optimization of both processes [5]. Biogas purification that can be applied in Indonesia is pressure swing absorption (PSA). In the PSA process, the biogas is compressed with a pressure between 4-10 bars and fed to the vessel (column) which is included with the material (adsorbent) which will selectively retain $\mathrm{CO}_{2} \cdot \mathrm{CH}_{4}$ gas is purified at the top of the column with a very small pressure drop. After a certain time, the adsorbent is saturated with $\mathrm{CO}_{2}$ and the column needs to be regenerated by reducing the pressure (usually for vacuum, to upgrade biogas) [6].

In this study $\mathrm{CO}_{2}$ will be absorbed by absorbent from the substrate itself. Absorbents such as water can dissolve $\mathrm{CO}_{2}$ better and the use of substrate as absorbent can save water usage from outside the reactor. The reactor operation with circulation effluent can provide benefits, if the liquid waste to be treated has a high COD concentration or suspended solid, the rate of degradation of organic matter can reach $75 \%-95 \%$ for liquid waste that does not contain solid material and only $40 \%-50 \%$ for liquid waste containing solids [7].

The purpose of this study was to determine the effect of substrate circulation on the removal of organic compounds and $\mathrm{CH} 4$ production in anaerobic fixed bed reactors.

\section{Methods}

The study was operated with two stage digester, the first digester for hydrolysis process from organic cafeteria waste, and the second digester was a fixed bed reactor anaerobic as a methanogen reactor, with a volume of 180 liters containing a sponge filter media in the form of cubes of $2 \mathrm{~cm}$ each side, Fixed bed media serves to place growth and multiply microbes [8], rector equipped with gas holder to hold gas.

* Corresponding author: etih@itenas.ac.id 
Organic waste, of cafetaria was put into the hydrolysis reactor until leachate was formed and then leachate as a substrate for the methanogen reactor. Seeding and acclimatization are carried out in the methanogen reactor by giving leachate gradually until the steady state conditions

The reactor is operated with a variation of hourly leachate circulation which is $0.30,0.32$ and 0.33 , each circulation is carried out three times. According to [7], the circulation of substrates that have COD and high suspended solid can reduce organic matter by $75 \%$ $95 \%$. In this study the pressure on the methanogen reactor was higher than that of the stripper reactor, the pressure in the 1 bar methanogen reactor and the stripper reactor -1 bar and each was equipped with a gas holder.

Sampling was carried out on methanogen reactor influent and effluent, parameters were analyzed for temperature, $\mathrm{pH}$ (potentiometric method, SNI 066989.11.2004) [9], TVA (distillation-Standard Method for the Examination of Water and Wastewater 5560-C), COD (closed Titrimetri-Reflux, Standard Method for the Examination Water and Wastewater 5220-C) [10] and biogas (orsat method). Reactor configuration as shown in Figure 1.

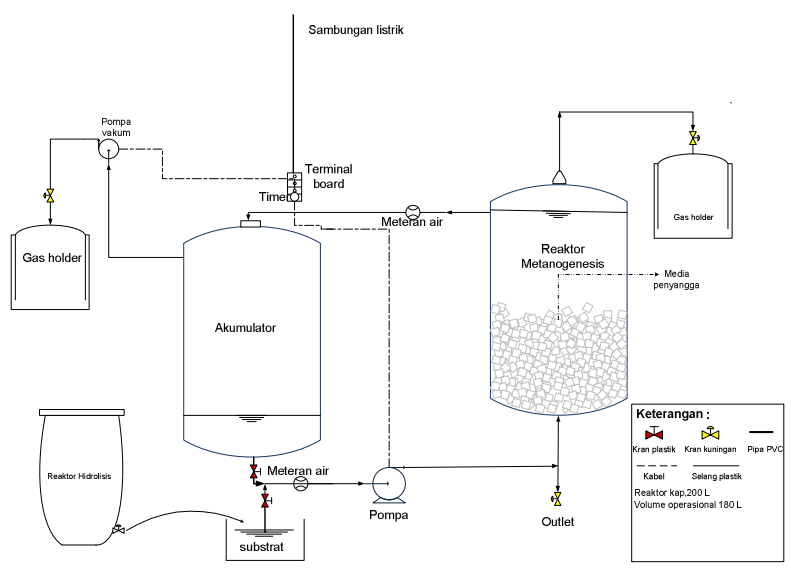

Fig 1. Reactor configuration

\section{Result and Discussion}

\subsection{Substrate characteristics}

Measurements of leachate characteristics were carried out to determine the condition of leachate as a substrate to be used as a feed for methanogen reactors to be processed into biogas, and suitable for biological processing.

Table 1. Substrate characteristics

\begin{tabular}{|l|l|l|}
\hline Parameter & Unit & Substrate \\
\hline Temperatur & ${ }^{\circ} \mathrm{C}$ & 24.9 \\
\hline $\mathrm{pH}$ & - & 6.57 \\
\hline BOD & $\mathrm{mg} / \mathrm{L}$ & 5,085 \\
\hline $\mathrm{COD}$ & $\mathrm{mg} / \mathrm{L}$ & 9,053 \\
\hline Ratio BOD/COD & - & 0.56 \\
\hline
\end{tabular}

Substrate characteristic measurement results have a temperature of $24.9^{\circ} \mathrm{C}$ and the value is in the mesophilic range $\left(20-45^{\circ} \mathrm{C}\right)$ needed for microbial growth. Leachate $\mathrm{pH}$ is 6.57 , this value is in the $\mathrm{pH}$ range where bacteria can grow well in the $\mathrm{pH}$ range 6.6-7.6 [11].

If the BOD / COD ratio is greater than 0.5 , it is suitable to use biological processing [12], on the characteristics of leachate that is 0.56 which meets the above so that the leachate is suitable for biological processing.

\subsection{Temperature}

In this study the temperature is in the range 25.52 $25.750 \mathrm{C}$ as in table 1 . The measured temperature conditions during observation are in mesophilic conditions. Mesophilic range is $20-45^{\circ} \mathrm{C}$ [13].

Setting a constant temperature is more important than maintaining a temperature that gives a maximum rate in the methanogenesis process because methanogen bacteria are slower to adjust to changes in conditions than acidogenic bacteria. This causes the accumulation of organic acid products. As a result, there will be an imbalance that can lead to process failure [14]. The selection of mesophilic conditions is based on the reaction in the digester, where at low temperatures $\left(<40^{\circ} \mathrm{C}\right)$, the reaction is more stable and usually requires less energy, but the reaction speed is slow.

Temperature can affect the biological system in two ways, namely affecting the speed of the enzymatic reaction and the speed of diffusion of the substrate into the cell. However, the difference in the kinetics rate of microorganisms will double when there is a temperature increase of $10^{\circ} \mathrm{C}$ to critical conditions $\left(60^{\circ} \mathrm{C}\right)$.

Table 1. Temperature in circulation variation

\begin{tabular}{|c|c|}
\hline $\begin{array}{c}\text { Volumetric } \\
\text { (circulation/hour) }\end{array}$ & $\begin{array}{c}\text { Temperature } \\
\left({ }^{\circ} \mathrm{C}\right)\end{array}$ \\
\hline 0.30 & 25.52 \\
\hline 0.32 & 25.75 \\
\hline 0.33 & 25.57 \\
\hline
\end{tabular}

\subsection{Relationship of $\mathrm{pH}$, TVA dan Alkalinity}

The $\mathrm{pH}$ value is an important parameter in biogas production, because methanogen bacteria grow in the neutral $\mathrm{pH}$ range, which is 6.8-7.2 and can work well in the $\mathrm{pH}$ range 6.6-7.6 [11]. Alkalinity as a buffer in the process of biogas formation so that the $\mathrm{pH}$ tends to be stable in the environmental conditions of methanogenic bacteria.

Table 2. $\mathrm{pH}$, TVA and ratio TVA/alkalinity

\begin{tabular}{|c|c|c|c|c|}
\hline \multirow{2}{*}{$\begin{array}{l}\text { Volumetric } \\
\text { (circ/hour) }\end{array}$} & \multicolumn{2}{|c|}{$\mathbf{p H}$} & \multirow{2}{*}{$\begin{array}{c}\text { TVA } \\
\text { (mg/L } \\
\text { acetat) }\end{array}$} & $\begin{array}{c}\text { Ratio } \\
\text { TVA/alka } \\
\text { linity }\end{array}$ \\
\hline 0.30 & 5.66 & 7.62 & 1,540 & 0.28 \\
\hline 0.32 & 5.19 & 7.47 & 1,470 & 0.27 \\
\hline 0.33 & 5.22 & 7.51 & 1,078 & 0.19 \\
\hline
\end{tabular}


Based on table 2, the $\mathrm{pH}$ of reactor $7.47-7.62$, the value is in the $\mathrm{pH}$ range of methanogenic bacteria can grow. The $\mathrm{pH}$ value which is relatively stable and is in the $\mathrm{pH}$ range of biogas formation indicates sufficient buffer capacity in the reactor [15]. Alkalinity values to maintain a stable $\mathrm{pH}$ is at least $2000 \mathrm{mg} / \mathrm{L} \mathrm{CaCO}_{3}$ [13], the results of measurements of alkalinity values in the reactor are more than $2000 \mathrm{mg} / \mathrm{L} \mathrm{CaCO}_{3}$. The TVA ratio: alkalinity $<0.4-0.5$ anaerobic process will take place without excessive acidification [16], the results of the study in table 1 obtained ratio TVA to alkalinity is $<$ 0.4 so that the process can take place both in producing biogas.

\subsection{Circulation variation on TVA and biogas}

Total volatile acid (TVA) is a source of organic acids for biogas formation. TVA value will decrease due to ongoing methanogenesis process, with this circulation volumetric variation will treatment the remaining TVA in the substrate during circulation,

so that methanogenic microorganisms will convert back TVA in the substrate to biogas. The following is a figure 2 of the effect of circulation volumetric variation on TVA degradation during the biogas formation process.

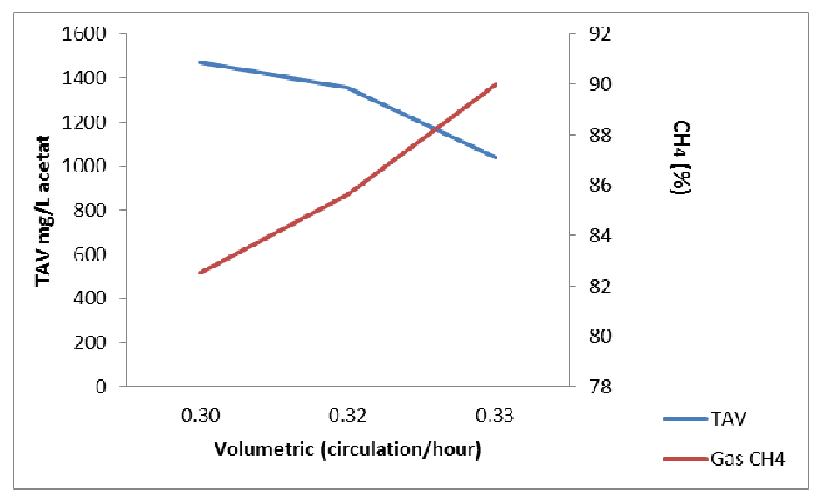

Fig 2. Effect of circulation volumetric on TVA and CH4.

\subsection{Circulation variation for COD removal and $\mathrm{CH}_{4}$ increase}

Chemical Oxygen Demand (COD) is the amount of oxygen needed to oxidize organic compounds, so it can be said that the COD parameter is a parameter to determine the concentration of organic compounds that can be oxidized by strong oxidizing agents in acidic environments. According to [17], the anaerobic process is suitable for waste with a COD concentration of 2,000 to more than $20,000 \mathrm{mg} / \mathrm{L}$ total COD.

The reactor operation with circulation effluent can provide benefits, if the liquid waste to be treated has high COD concentrations or suspended solids, the rate of degradation of organic matter can reach $75 \%$ to $95 \%$ for wastewater that does not contain solid material and only $40 \%$ to $50 \%$ for liquid waste containing solids [7].

The COD value that is entered into the reactor is not regulated but still in anaerobic processing range, and because the reactor used is a fixed bed reactor, the processing is able to degrade high COD values.

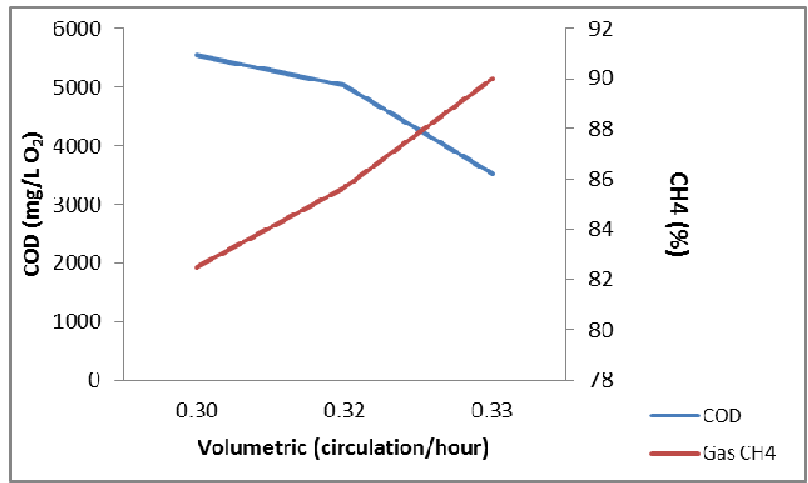

Fig 3. The volumetric effect of circulation on $\mathrm{COD}$ and $\mathrm{CH}_{4}$

Based on $\mathrm{COD}$ and $\mathrm{CH}_{4}$ measurements in figure 3 shows the smallest $\mathrm{COD}$ value of $3.520 \mathrm{mg} / \mathrm{L} \mathrm{O}_{2}$ in the volumetric circulation 0.33 per hour, because the more often the circulation is carried out the substrate will be more frequent in contact with microorganisms. this causes more organic matter to be degraded, so the COD value will decrease. This decrease in COD value indicates that more organic matter is degraded and converted to $\mathrm{CH}_{4}$, then $\mathrm{CH}_{4}$ gas production will be higher.

\subsection{Circulation variation in $\mathrm{CH}_{4}$ concentration}

Pressure swing absorption technology used has been widely tested in various industries to purify gas from impurities with different pressures, the application of circulation of this effluent substrate is expected to improve biogas purification

The results showed that the concentration of methane was higher with pressure swing absorbtion technology and higher as the volume of volumetric circulation was carried out which reached $90 \% \mathrm{CH}_{4}$ concentration at 0.33 circulation/hour. This substrate also becomes an absorbent to absorb $\mathrm{CO}_{2}$ in the methanogen reactor and $\mathrm{CO}_{2}$ will be released into the gas phase when strippered, the reactor is operated with vacuum pressure circulation so that the organic substances in the remaining substrate can be degraded back into biogas. Figure 4 shows the effect of volumetric circulation variation on the purity of biogas.

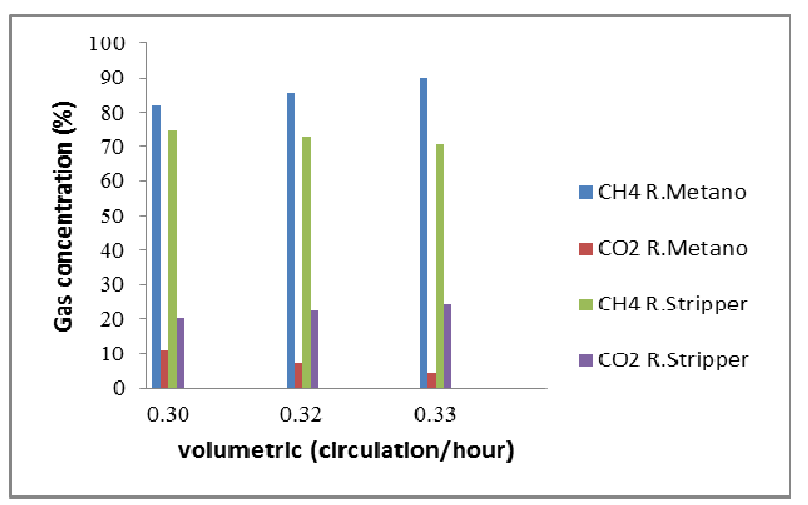

Fig 4. Volumetric Effect of Circulation on $\mathrm{CH}_{4}$ and $\mathrm{CO}_{2}$ Concentrations. 
With the depletion of fossil energy reserves, processing organic waste into renewable energy can provide alternative options that can be said to be able to overcome two problems at once, namely the problem of waste and energy crisis.

\section{Conclusion}

Based on the analysis and discussion can be concluded that biogas purification by pressure swing absorption technology in a series of anaerobic fixed bed reactor can be applied and produce biogas purity better than the results of conventional biogas. The application of circulation variation in the biogas purification process produces the highest biogas purity in the circulation volumetric variation of 0.33 circulation / hour with results of $\mathrm{CH}_{4}$ gas by $90 \%$.

The application from this research can contribute for using leachate to produce biogas $\mathrm{CH}_{4}$ and can be use as a fuel.

\section{Reference}

1. Juanga, J. P., Visvanathan, C., et al. Optimization of anaerobic digestion of municipal solid waste in combined process and sequential staging. Waste management \& research (2007)

2. Sutarno, S. Analisis Prestasi Produksi Biogas $\left(\mathrm{CH}_{4}\right)$ Dari Polyethilene Biodigester Berbahan Baku Limbah Ternak Sapi. Jurnal Logika (2007).

3. Wahyuni, S. (2011). Menghasilkan Biogas dari Aneka Limbah. Jakarta (ID): Agro Media Pustaka.

4. Sitorus, B., \& Panjaitan, S. D. Biogas recovery from anaerobic digestion process of mixed fruit-vegetable wastes. Energy Procedia (2013)

5. Llabres-Luengo, P., \& Mata-Alvarez, J. The hydrolytic step in a dry digestion system. Biological wastes (1988)

6. Grande, C. A. Biogas upgrading by pressure swing adsorption: INTECH Open Access Publisher (2011)

7. Indriyati, I. Pengolahan Limbah Cair Organik Secara Biologi Menggunakan Reaktor Anaerobik Lekat Diam. Jurnal Air Indonesia (2011)
8. Chavadej, S. Anaerobic filter for biogas production. Paper presented at the UNESCO, Workshop on Energy from Biomass and Wastes, University of Peradeniya, Peradeniya, Sri Lanka, Nov. 26-30, 1979. Regional Journal of Energy, Heat and Mass Transfer, vol. 2, Jan. 1980, p. 31-44. Research supported by the National Research Council of Thailand (1980)

9. SNI 06-6989.11.2004. Air dan air limbah, Bagian 11: Cara uji derajat keasaman $(\mathrm{pH})$ dengan menggunakan alat $\mathrm{pH}$ meter (2004)

10. APHA. Standard methods for the examination of water and wastewater. Washington, DC Standard Methods for the Examination of Water and Wastewater, 4 Ed (1999)

11. Eckenfelder, W. W. Industrial water pollution control: McGraw-Hill (1989)

12. G.Tchobanoglous, F.L.Burton. Wastewater Engineering:treatment, disposal and reuse, McGraw-Hill International (2003)

13. Speece, R. E. Anaerobic biotechnology for industrial wastewaters Anaerobic biotechnology for industrial wastewaters (1996)

14. Buekens, A. Energy Recovery From Residual Waste By Means of Anaerobic Digestion Technologies. Vrije Universiteit Brussel, Pleinlaan 2, B-1050, Brussel (2005)

15. Ramdhani, M. D., \& Handajani, M. Material Penyisihan Senyawa Organik Pada Biowaste Fasa Cair Menggunakan Upflow Anaerobic Fixed Bed Reactor Dengan Media Penunjang Bambu (2009)

16. Umana, O., Nikolaeva, S., et al. Treatment of screened dairy manure by upflow anaerobic fixed bed reactors packed with waste tyre rubber and a combination of waste tyre rubber and zeolite: effect of the hydraulic retention time. Bioresource technology (2008)

17. Malina, J. Design of anaerobic processes for treatment of industrial and muncipal waste (Vol. 7): CRC Press (1992) 